\title{
Socially responsible practices: Manifested commitment in universities
}

\section{Prácticas socialmente responsables: Compromiso manifiesto en las universidades}

RIVERA-IRIBARREN, Maricel†*, CALDERÓN-SOTO, Lorena, SALGUERO-CRUZ, Yizel Carolina and BELTRAN-CUEN, Carolina

\author{
Instituto Tecnológico de Sonora
}

ID $1^{\text {st }}$ Author: Maricel Rivera-Iribarren / ORC ID: 0000-0003-1823-0149, Researcher ID Thomson: S-7893-2018, CVU CONACYT ID: 896629

ID $1^{\text {st }}$ Coauthor: Lorena, Calderón-Soto / ORC ID: 0000-0002-8407-831X, Researcher ID Thomson: S-7886-2018, CVU CONACYT ID: 22017

ID $2^{\text {nd }}$ Coauthor: Yizel Carolina, Salguero-Cruz / ORC ID: 0000-0002-4958-0590, CVU CONACYT ID: 1011175

ID $3^{\text {rd }}$ Coauthor: Carolina, Beltrán-Cuen / ORC ID: 0000-0003-4264-726X, CVU CONACYT ID: 1013332

DOI: $10.35429 / J S E M .2019 .18 .6 .33 .40$

Received February 02, 2019; Accepted June 29, 2019

\begin{abstract}
The deep and constant transformations at a global level, have led the higher educational institutions to rethink their social function, requiring the formation of individuals sensitive to the social problems that afflict the community, assuming social responsibility (RS) as a guiding axis for the social transformation; being this one of the main indicators in terms of educational quality stipulated by the ANUIES. Different research has shown that although there is a positive perception of the educational community about SR, there is no common regulatory framework for its development, which allows the unification of acting within the institution. The objective of this cross-sectional quantitative study is to determine the frequency with which the principles and values of the university are presented in a public university in Sonora from the student perspective, applying an instrument composed of 66 items to 100 students. The main results show the need to deepen in areas such as inclusion, democracy, participation, and freedom mainly.
\end{abstract}

Social responsability, Socially responsible practice, Participation

\begin{abstract}
Resumen
Las profundas y constantes transformaciones suscitadas a nivel global, han llevado a las instituciones educativas a replantear su función social, requiriendo la formación de capital humano cercano y sensible a las problemáticas sociales que aquejan a la comunidad, asumiendo la responsabilidad social (RS) como un eje rector para la transformación de la sociedad; siendo este uno de los principales indicadores en términos de calidad educativa estipulados por la ANUIES. Diversas investigaciones han evidenciado que a pesar de haber una percepción positiva por parte de la comunidad educativa en relación a la RS no existe un marco normativo común para su desarrollo, que permita la unificación del actuar dentro de la institución. Este es un estudio cuantitativo tipo transversal, en el que se contó con la participación de 100 estudiantes a quienes se les aplicó un instrumento compuesto por 66 ítems, con el objetivo de determinar la frecuencia en la que se presentan los principios y valores de la universidad desde la perspectiva estudiantil en una universidad pública de Sonora. Los principales resultados ponen de manifiesto la necesidad de profundizar en áreas como inclusión, democracia, participación, libertad, entre otros.
\end{abstract}

Responsabilidad social, Práctica socialmente responsable, Participación

Citation: RIVERA-IRIBARREN, Maricel, CALDERÓN-SOTO, Lorena, SALGUERO-CRUZ, Yizel Carolina and BELTRAN-CUEN, Carolina. Socially responsible practices: Manifested commitment in universitiesJournal of Systems and Educational Management. 2019. 6-18: 33-40

\footnotetext{
* Correspondence to Author (email: xparra@laselva.edu.mx)

$\dagger$ Researcher contributing as first author.
} 


\section{Introduction}

The University, as a training and dynamic change entity, is committed to providing a more global vision of the world, with a fully developed community sense (Naranjo, 2005 cited by Corrales, 2007). Thus, higher education institutions have the task of acting under a framework of social responsibility, so it is necessary a training process that favors the development of skills that allow students to be able to have close contact with the community, such and as stated by Gaete (2015).

The deep and constant transformations provoked at a global level have led educational institutions to rethink their social function, requiring the formation of close human capital and sensitive to the social problems that afflict the community, assuming social responsibility (RS) as a guiding axis for the transformation of society (Batz and Gutiérrez, 2009).

Given the role of the university as a generating agent of new knowledge and of professionals capable of motorizing the social, political and economic transformations demanded by society in search of sustainable human development, their involvement in an active and decisive manner before the Problems of the 21st century (Medina et al. 2017).

Against this background, ANUIES (2012) urges universities to direct their efforts towards solving problems at a social level, demanding a paradigm shift, in which it is not only enough to know the problems and present remedies that will not transcend, nor will they have a impact. Being considered a socially responsible body is not a matter of distinctiveness, it implies the promotion of lasting changes in its processes and in the philosophy itself (Alfaro, s / f).

Currently, universities develop numerous actions that seek to favor university social responsibility (RSU), however these are carried out independently without being coordinated under a common framework, that is, they are taken into account in a segmented manner and not as a model (Fernández, 2013). Only part of the university community is informed about the requirements of the RSU and consequently there is no application of it; So generating a model oriented to guide these practices is pressing, as stated by Vallaeys (2014).
Therefore, it is urgent to generate changes in the structures that enable the educational community to enter into social commitment and responsibility, open spaces for the exchange of experiences, the expression of concerns and the search for social participation. The university must resume its position as a change agent and make the necessary movements for the integral development of its students (Inglada and Sastre, 2016).

Studies in this area have shown the presence of behaviors that characterize the actions of a socially responsible university, however it is necessary to ensure that these are not isolated events, but a constant in their daily actions, where professionals in training acquire the knowledge, skills and attitudes necessary to act in their environment and in favor of it. Based on the above, there is a need to identify to what extent the principles and values of the university are manifested from the student perspective in the university?

The objective of this study is to determine the frequency in which the principles and values of the university are presented from the student perspective in a public institution in Sonora, based on the proposal by Vallaeys (2014), who establishes two dimensions to determine the behaviors and values that characterize a socially responsible university: 1) those related to life in society and 2) specific values and principles of the university.

The objective of this study is to determine the frequency in which the principles and values of Barffusón \& Katra (2010) are presented, establish that responsibility is a value whose impact on society is of utmost importance, since it depends on the welfare of people, society and the planet; Being responsible implies becoming aware of the duties and obligations and assuming them responding with reasons; hence the importance of the university as a training and dynamic entity of changesuniversity from the student perspective in a public institution of Sonora, from the proposal of Vallaeys (2014), who establishes two dimensions to determine the behaviors and values that characterize a socially responsible university: 1) those related to life in society and 2) specific values and principles of the university. 
The Declaration of Talloires (2005), cited by Collazo (2014), raises the importance of Higher Education Institutions (HEIs) in social development, visualizing them as entities created to serve and strengthen the society of which it is a part, to through its educational and research processes, actively participating in society and contributing to the construction of a culture of reflection and action.

In this sense, Medina et al (2017), suggests that the university should promote social responsibility from its substantive functions; Therefore, the RSU must be present implicitly and explicitly in all the training processes that take place in it, in order to ensure that citizens are involved responsibly with the current challenges. So it can be visualized as a way for the student to develop integrally, generating actions that contribute to quality improvement.

From this perspective, Arango et al (2014) affirms that the RSU implies orienting the formation of students towards the development of social awareness, as an element for solving problems, through actions that consider the needs of In addition, providing them with interpersonal skills that allow them a better understanding and empathy (Valleys and De la Cruz, 2009, cited by Arango et al, 2014).

In the words of Martí and Martí (2010), a socially responsible student is a person with the ability to commit, listen and put himself in the place of the other, a citizen and empathic citizen, concerned not only with his well-being but with that of all that surround him. Higher education institutions must practice the RSU, which implies a legitimate commitment of the authorities to implement policies in this field, through their curricular proposals and the interdisciplinary practices approach; providing students with a complete understanding of the society in which they operate, implying an awareness of active and committed participation (Collazo, 2014).

\section{Method}

This is a descriptive quantitative transactional study, applied in the field; Data collection was carried out in a single moment seeking to identify the frequency in which the behaviors that characterize a university from the university social responsibility are performed.
The participation of 100 undergraduate students from different educational programs, whose ages range between 18 and 21 years of age, was considered, to which the questionnaire proposed by Universidad Construye País was applied, which consists of 66 items, using a Likert scale with five response options that range from never to forever.

Its objective was to identify the frequency of actions and behaviors that characterize a socially responsible university, considering nine categories of analysis: dignity of the person; freedom; citizenship; democracy and participation; sociability and solidarity; common good and equity; acceptance and appreciation of diversity; commitment to the truth; integrity; interdepence and interdiscipline. The information processing was carried out through the statistical package for Social Sciences SPSS version 21.0

\section{Results and Discussion}

The instrument applied for the collection of information considers two categories of analysis: principles and values of university life related to life in society and specific principles and values of the university. For the purposes of this study, only the items that are essential and essential in university activity, associated with the social responsibility training of the students were considered.

The first section of the instrument considers the principles and values of university life related to life in society, which is composed of six sub-scales, where the highest average was sociability and solidarity for coexistence with 3.55 points which in the scale used means 'almost always'; and the child was very common and social equity with 3.05 remaining in the same option of 'almost always'.

\begin{tabular}{|l|c|}
\hline \multicolumn{1}{|c|}{ Item } & M \\
\hline Dignity of the person & 3,39 \\
\hline Freedom & 3,25 \\
\hline Citizenship, democracy and participation & 3,46 \\
\hline Sociability and solidarity for living together & 3,55 \\
\hline Common good and social equity & 3,05 \\
\hline Acceptance and appreciation of diversity & 3,51 \\
\hline
\end{tabular}

Table 1 Descriptive items of the category principles and values of university life related to life in society 
Below are the scores obtained in the items that were considered essential and that attract attention when presented regularly and not permanently.

\begin{tabular}{|l|r|r|r|}
\hline Item & Min & \multicolumn{1}{|c|}{ Max } & M \\
\hline $\begin{array}{l}\text { 5. Demands respect for the person } \\
\text { in the work with human beings that } \\
\text { is entrusted to students }\end{array}$ & 2 & 4 & 3,46 \\
\hline $\begin{array}{l}\text { 6. Provides facilities for pregnant } \\
\text { or young children to study }\end{array}$ & 1 & 4 & 3,44 \\
\hline $\begin{array}{l}\text { 3. Invest to maintain good study } \\
\text { conditions for your students }\end{array}$ & 1 & 4 & 3,42 \\
\hline $\begin{array}{l}\text { 2. Expresses concern for the } \\
\text { respect teachers give to their } \\
\text { students }\end{array}$ & 1 & 4 & 3,25 \\
\hline
\end{tabular}

Table 2 Descriptive of the items of the person's dignity sub-scale

In table 2 you can see the average of each of the items of the dignity sub-scale of the person where you want to measure the conditions in which each member of the community can fully deliver their original and own contribution to the work of she. It is important to note that the item with the highest score on this scale was number five "it demands respect for the person in the work with human beings that is entrusted to students" who obtained an average of 3.46 points (almost always). The item with the lowest score on this scale was number two "expresses concern for the respect teachers give their students" with an average of 3.25 points (almost always).

\begin{tabular}{|l|r|r|r|}
\hline \multicolumn{1}{|c|}{ Item } & Min & Max & M \\
\hline $\begin{array}{l}\text { 10. Encourage your students to } \\
\text { freely assume social commitments }\end{array}$ & 2 & 4 & 3,40 \\
\hline $\begin{array}{l}\text { 9. It encourages teachers to give } \\
\text { freedom for students to express } \\
\text { their thoughts }\end{array}$ & 1 & 4 & 3,36 \\
\hline $\begin{array}{l}\text { 8. Gives spaces for students to } \\
\text { freely express their own ideas and } \\
\text { beliefs. }\end{array}$ & 1 & 4 & 3,33 \\
\hline $\begin{array}{l}\text { 12. Promotes open discussion of } \\
\text { issues that generate conflict in } \\
\text { society. }\end{array}$ & 1 & 4 & 2,93 \\
\hline
\end{tabular}

Table 3 Descriptive items of the sub-scale of freedom

In the sub-scale of freedom (table 3) that seeks to measure respect for the rights and freedoms of all members of the university community, the item with the highest score was "encourages its students to freely assume social commitments" with an average of 3.40 (almost always) while the item with the lowest score is "promotes open discussion of issues that generate conflict in society" with an average of 2.93 points (almost always).

\begin{tabular}{|l|l|l|l|l|}
\hline \multicolumn{1}{|c|}{ Item } & Min & Max & M \\
\hline $\begin{array}{l}\text { 17. He is interested in training } \\
\text { students in respect for human } \\
\text { rights. }\end{array}$ & 1 & 4 & 3,49 \\
\hline $\begin{array}{l}\text { 18. Contributes to form opinions on } \\
\text { public issues relevant to the } \\
\text { community. }\end{array}$ & 1 & 4 & 3,43 \\
\hline
\end{tabular}

Table 4 Descriptive of the items of the sub-scale of citizenship, democracy and participation

Table 4 shows the average of each of the items of the sub-scale citizenship, democracy and participation that refers to developing the reflective spirit, the development of personal judgment, fraternal solidarity and the attitude of free and responsible participation. The item with the highest score on this scale was number 17 "interested in training students in respect for human rights" which obtained an average of 3.49 points (almost always). The item with the lowest score on this scale was number 18 "contributes to form opinion on public issues relevant to the community" with an average of 3.43 points (almost always).

\begin{tabular}{|l|r|r|l|}
\hline Item & Min & Max & M \\
\hline $\begin{array}{l}\text { 21. Promotes respectful treatment } \\
\text { to all people, without distinction. }\end{array}$ & 2 & 4 & 3,62 \\
\hline $\begin{array}{l}\text { 19. Encourage students to provide } \\
\text { services to people, groups or } \\
\text { communities of limited }\end{array}$ & 2 & 4 & 3,53 \\
\hline $\begin{array}{l}20 \text { Stimulates solidarity among } \\
\text { students. }\end{array}$ & 2 & 4 & 3,52 \\
\hline
\end{tabular}

Table 5 Descriptive of the sub-scale items of sociability and solidarity for living together

In the sub-scale of sociability and solidarity for coexistence (table 5) that seeks to measure the identity of belonging and selfaffirmation of those who make up the educational community, the item with the highest score was "promotes respectful treatment to all people without distinction "with an average of 3.62 (almost always) while the item with the lowest score is" promotes open discussion of issues that generate conflict in society "with an average of 3.52 points (almost always). 


\begin{tabular}{|l|l|l|c|}
\hline \multicolumn{1}{|c|}{ Item Min } & Max & M \\
\hline $\begin{array}{l}\text { 27. Provides facilities for low- } \\
\text { income students to enter it. }\end{array}$ & 1 & 4 & 3,53 \\
\hline $\begin{array}{l}\text { 26. It gives importance to social } \\
\text { justice in the training of its students. }\end{array}$ & 1 & 4 & 3,40 \\
\hline $\begin{array}{l}\text { 30. Gives special support to } \\
\text { students who have emotional or } \\
\text { psychological problems. }\end{array}$ & 1 & 4 & 2,23 \\
\hline
\end{tabular}

Table 6 Descriptive of the items of the sub-scale of common good and equity

Table 6 shows the average of each of the items of the sub-scale common good and equity, which refers to the development of the institution through an equitable participation of resources and the social assessment of professionals trained in University. The item with the highest score on this scale was number 27 "it provides facilities for low-income students to enter it" which obtained an average of 3.53 points (almost always). The item with the lowest score on this scale was number 30 "gives special support to students who have emotional or psychological problems" with an average of 2.23 points (almost always).

\begin{tabular}{|l|r|r|r|}
\hline \multicolumn{1}{|c|}{ Item Min } & Max & M \\
\hline $\begin{array}{l}\text { 37. Act with respect for the human } \\
\text { diversity in it (races, nationalities, } \\
\text { cultures, etc.) }\end{array}$ & 1 & 4 & 3,67 \\
\hline $\begin{array}{l}\text { 41. It gives ease of access to } \\
\text { special groups (disabled, } \\
\text { indigenous, etc.). }\end{array}$ & 1 & 4 & 3,54 \\
\hline $\begin{array}{l}\text { 40. Make forums and panels so } \\
\text { that its members know the } \\
\text { different positions that are faced } \\
\text { with problems of national interest. }\end{array}$ & 2 & 4 & 3,32 \\
\hline
\end{tabular}

Table 7 Descriptive items of the sub-scale of acceptance and appreciation of diversity

In the sub-scale of acceptance and appreciation of diversity (table 7) that seeks to measure the ability to value the other and integrate it into society without discrimination based on race, sex, age, religious, social or political status. The item with the highest score was "act with respect for the human diversity in it (races, nationalities, cultures, etc.) without distinction" with an average of 3.67 (almost always) while the item with the lowest score is "perform forums and panels so that its members know the different positions that are faced with problems of national interest "with an average of 3.32 points (almost always).

\begin{tabular}{|l|c|}
\hline \multicolumn{1}{|c|}{ Item } & M \\
\hline Commitment to the truth & 3,39 \\
\hline Integrity & 3,49 \\
\hline Interdependence and interdisciplinary & 3,48 \\
\hline
\end{tabular}

Table 8 Descriptive items of the category principles and specific values of the university

The second section of the instrument considers the specific principles and values of the university, is composed of three sub-scales, where the highest average was integrity with 3.49 points which in the scale used means 'almost always'; and the minor was a commitment to the truth with 3.48 remaining in the option of 'almost always'. In the same way, the scores obtained are broken down in the items that were considered essential and that attract attention when presented regularly and not permanently.

\begin{tabular}{|l|r|r|r|}
\hline \multicolumn{2}{|c|}{ Item Min } & Max & M \\
\hline $\begin{array}{l}\text { 47. Recognizes the commitment } \\
\text { to the truth of its members. }\end{array}$ & 1 & 4 & 3,44 \\
\hline $\begin{array}{l}\text { 45. Make an honest and } \\
\text { transparent internal } \\
\text { communication. }\end{array}$ & 1 & 4 & 3,40 \\
\hline $\begin{array}{l}\text { 43. He carries out his teaching } \\
\text { with a strong attachment to the } \\
\text { truth without accommodating or } \\
\text { hiding it to satisfy particular } \\
\text { interests. }\end{array}$ & & & \\
\hline
\end{tabular}

Table 9 Descriptive of the items of the sub-scale commitment to the truth

Table 9 shows the average of each of the items of the sub-scale commitment to the truth that refers to the primordiality of knowledge and fundamental values, as well as its immediate use or application. The item with the highest score on this scale was number 47 "acknowledges the commitment to the truth of its members" which obtained an average of 3.44 points (almost always). The item with the lowest score was number 43 "he teaches with a strong attachment to the truth without accommodating or hiding it to satisfy particular interests" with an average of 3.36 points (almost always). 


\begin{tabular}{|l|r|r|r|}
\hline \multicolumn{1}{|c|}{ Item } & Min & Max & M \\
\hline $\begin{array}{l}\text { 49. It has written and known } \\
\text { ethical criteria by the university to } \\
\text { guide the behavior of its members }\end{array}$ & 1 & 4 & 3,52 \\
\hline $\begin{array}{l}\text { 54. Promotes that students respect } \\
\text { intellectual property }\end{array}$ & 2 & 4 & 3,50 \\
\hline $\begin{array}{l}\text { 50. Its authorities show coherence } \\
\text { between its principles and its } \\
\text { actions. }\end{array}$ & 2 & 4 & 3,45 \\
\hline $\begin{array}{l}\text { 52. The behavior of teachers is } \\
\text { consistent with the ethical criteria } \\
\text { that the university has. }\end{array}$ & 1 & 4 & 3,32 \\
\hline $\begin{array}{l}\text { 51. Teachers are strict in the face } \\
\text { of academic dishonesty behavior } \\
\text { of their students. }\end{array}$ & 1 & 4 & 3,24 \\
\hline
\end{tabular}

Table 10 Descriptive items of the integrity sub-scale

Table 10 shows the average of each of the items of the integrity sub-scale that refers to the coherence of acting with principles and values, both in their statements and in their actions being straight, transparent and honest. The item with the highest score on this scale was number 49 "it has written and known ethical criteria by the university to guide the behavior of its members", which obtained an average of 3.52 points (almost always). The item with the lowest score on this scale was number 51 "teachers are strict in the face of academic dishonesty behavior of their students" with an average of 3.24 points (almost always).

\begin{tabular}{|l|r|r|r|}
\hline \multicolumn{1}{|c|}{ Item } & Min & Max & M \\
\hline $\begin{array}{l}\text { 66. Promotes the link of } \\
\text { university activities with the local } \\
\text { community. }\end{array}$ & 1 & 4 & 3,51 \\
\hline $\begin{array}{l}\text { 65 It encourages academic } \\
\text { activities to address the } \\
\text { challenges or problems facing } \\
\text { our society }\end{array}$ & 1 & 4 & 3,47 \\
\hline
\end{tabular}

Table 11 Descriptive of the items of the interdependence and interdisciplinary sub-scale

The interdependence and interdisciplinary sub-scale (table 11) seeks to measure the dynamic relationship between the university and society, recognizing their mutual need and requiring a permanent dialogue. In this, the item with the highest score was "promotes the link between university activities and the local community" with an average of 3.51 (almost always) while the item with the lowest score is "conducive for academic activities to address the challenges or problems facing our society "with an average of 3.47 points (almost always).
It is important to highlight that in the processes of knowledge formation, necessary for the formation of socially responsible people, the teacher plays a key role being a model for the student body; Therefore, full compliance with the ethics criteria in the institution is crucial, since there are behaviors that cannot be presented intermittently. Not only are contents or objectives sufficient, it is necessary that social methods be present in methods, teaching methods and media (Medina et al, 2017).

In the same way these behavior patterns apply towards the interior of the university, the identity and solidarity in the students cannot be developed without the commitment of all the actors of the educational community, in the achievement of their conceptualization and practice. The involvement of the human resource generates commitment and interest to take the RSU beyond a circumstantial discourse and make it a habitual practice by conviction (Collazo, 2014).

The findings found in the items with reference to the freedom of expression that students have in the university, identify that the institution provides spaces to express themselves, encourages teachers to give freedom to expose their thoughts. However, it is not only enough to have spaces and freedom, it is necessary to fulfill one of the substantive functions of the university, which is to train critical and participatory citizens in the problems that afflict the community (Livia, 2016).

Regarding the dimension of interdependence and interdisciplinarity, it is important to highlight that the university promotes that students get involved and have a direct approach with the community when developing different projects, this in order to create a link and respond to social needs, however, this link with the real scenario should be aimed at achieving in the university the formation of a citizen and citizen aware of their duties and obligations, responsible for professional decisions, their doing or not doing and the consequences of these in their environment (Barffusón \& Katra, 2010). 


\section{Conclusions}

The evidence shows the university's concern to train citizens with social responsibility. Although the results indicate the presence of behaviors that make the university socially responsible, it is necessary that it orient its key processes through clearly defined values, establishing a position on clear and active social responsibility that allows the involvement of the entire school community, as stated by De la Calle (2012).

The institution is recommended to adopt a model of university social responsibility, according to Omura (2014) it is necessary to appropriate a transversal model to the entire university system, since this impacts both internal interest groups and groups of External interest For its part Valleys (2019) indicates that it is essential to know and understand the RSU since it requires a commitment of coresponsibility by the actors in the different functions of the university.

It is necessary to highlight that nowadays the importance of higher education students, together with their teachers, meets the axes established by the university for their training, in which the application of values is immersed, both increases. in his daily life as in the professional. UNESCO (2014) emphasizes efforts towards the orientation of teacher training, proposing an equitable benefit to students and society; Since if the teacher does not opt for a change, the priority actions in the educational processes that lead the student population to respond to the needs demanded by the community will be void. Young university students are and will always be the future of the country, so it is essential to permanently model these principles and values that impact within the place where they will be trained as integral, supportive and empathic professionals regarding the attention of the problems that surround it (Collazo, 2014).

When referring to the interdisciplinarity of universities, García et al. (2016) emphasize the need for the creation of links between university students, teachers and social agents, in order to transform universities into institutions that train citizens aware of social reality, and in turn, guide them to the search of a continuous improvement of the community.
Gasper (2013) considers that for the success of the actions implemented by the university in society, a teaching-learning process specifically aimed at the creation of integration scenarios is necessary, aimed at finding solutions to common complex problems and using the different disciplines that make up a profession.

To be able to say that it is a socially responsible university, it is necessary to assess the situation of the community in which it is immersed, being socially responsible implies an improvement in the quality of life of citizens, better health systems, greater security, a society fair, fair and not exclusive. That is why the university must commit to the training of new critical professionals, responsible, aware of the reality that afflicts their communities and committed to their actions.

\section{References}

Alfaro, J. (S/F). La responsabilidad social en las instituciones de Educación Superior ¿Valor obligatorio o transformación necesaria? Revista COEPES.

ANUIES (2012). Inclusión con responsabilidad social. Una nueva generación de políticas de educación superior. México, D.F.: ANUIES, Dirección de medios editoriales.

Arango, O, Clavijo, S, Puerta, I. \& Sánchez, J. (2014). Formación académica, valores, empatía y comportamientos socialmente responsables en estudiantes universitarios. Revista de Educación Superior, 43(169), 89-105. Recuperado de: http://publicaciones.anuies.mx/pdfs/revista/Rev ista169_S1A5ES.pdf

Batz, A. \& Gutiérrez, A. (2009). Inclusión social: una alternativa para la responsabilidad social empresarial. Ubicuidad y Responsabilidad Social. Revista Colombiana de Telecomunicaciones, 16, 1-66. Recuperado de: https://www.academia.edu/3254928/Inclusi\%C 3\%B3n_social_una_alternativa_para_la_respon sabilidad_social_empresarial

Barffusón, R. \& Katra, L. (2010). Responsabilidad social y compromiso social: desafíos educativos en una sociedad globallocal. XII Coloquio Internacional de Gestión Universitaria. Recuperado de: https://repositorio.ufsc.br/handle/123456789/97 849 ? show $=$ full

RIVERA-IRIBARREN, Maricel, CALDERÓN-SOTO, Lorena, SALGUERO-CRUZ, Yizel Carolina and BELTRAN-CUEN, Carolina. Socially responsible practices: Manifested commitment in universitiesJournal of Systems and Educational Management. 2019 
Collazo, C. (2014). La responsabilidad social universitaria (RSU) un compromiso ineludible. Kalathos Revista Transdisciplinaria MetroInter, 7 (2). $\quad$ Recuperado de: http://kalathos.metro.inter.edu/kalathos_mag/pu blications/La-Responsabilidad.pdf

Corrales, S. (2007). La misión de la universidad en el siglo XXI. Revista electrónica Razón y Palabra (57). Recuperado de: http://www.razonypalabra.org.mx/anteriores/n5 7/scorrales.html

De la Calle, C. (2012). Reflexión sobre la responsabilidad social corporativa en el siglo XXI. España:Ediciones Universidad de Salamaca.

Fernández, G. (2013). Responsabilidad social universitaria. Tesis de Maestría. Universidad de Oviedo. 38 p. Recuperado de: http://www.invurnus.uson.mx/revistas/articulos /22- MartinezDuranyCol2016EE.pdf

Gaete, R. (2015). El concepto de responsabilidad social universitaria desde la perspectiva de la alta dirección. Cuadernos de administración, 31(53), 97-107. Recuperado de: http://www.scielo.org.co/pdf/cuadm/v31n53/v3 1n53a09.pdf

García, J., Ramos, C., Gómez, J. D., Ramos, B. J. (2016). Necesidad de nuevos marcos organizativos universitarios desde la responsabilidad social universitaria. Revista de Ciencias Humanas y Sociales, No. 80.

Gasper, D. (2013). Interdisciplinariedad hacia una ecología compleja de las ideas. Ambiente y Sostenibilidad, $\quad 2, \quad 3-28$. Doi:10.25100/ays.v2i1.4323

Inglada, E. \& Sastre, J. (2016). Reflexiones sobre responsabilidad social empresarial, responsabilidad pública y la sostenibilidad medioambiental. Revista Galega de Economía, 25(3), 5-22.

Livia, J. (2016). El compromiso de la universidad con la responsabilidad social. Cátedra Villarreal 4(2), 229-234. Recuperado de:

http://revistas.unfv.edu.pe/index.php/RCV/artic le/view/78
Martí, J. y Martí, M. (2010). La responsabilidad social: ¿una universidad empática?. Revista Nou- Dice, 362 (4). Recuperado de: http://www.uv.es/noudise/362.pdf

Medina, R., Franco, M., Torres, L., Velázquez, K., Valencia, M., \& Valencia, A. (2017). La responsabilidad social universitaria en la actual sociedad del conocimiento. Un acercamiento necesario. MediSur, 15 (6), 786-791. Recuperado: de http://scielo.sld.cu/scielo.php? script=sci_arttext \&pid $=$ S1727-

897X2017000600006\&lng=es\&tlng=es

Omura, R. J. K. (2014). Modelos de Responsabilidad Social Universitaria. Gestión en el Tercer Milenio, 17(33), 39-44.

UNESCO (2014). Enseñanza y Aprendizaje: lograr la calidad para todos. Informe de seguimiento de la EPT en el mundo 2013 - 2014. París: UNESCO. Recuperado de: http://unesdoc.unesco.org/images/0022/002256/ 225654s.pdf

Vallaeys, F. (2014). La responsabilidad social universitaria: un nuevo modelo universitario contra la mercantilización. Revista Iberoamericana de Educación Superior, 5(12), 105-117. Recuperado de http://www.redalyc.org/pdf/2991/29912997700 6.pdf

Vallaeys, F. \& Álvarez, J. (2019). Hacia una definición latinoamericana de responsabilidad social universitaria. Aproximación a las preferencias conceptuales de los universitarios. Educación XX1, 22(1), 93-116, doi: 10.5944/educXX1.19442

\section{Agradecimiento}

Este proyecto fue financiado por el Programa para el Fomento y Apoyo a Proyectos de Investigación del Instituto Tecnológico de Sonora (PROFAPI 2019). 